\title{
Molybdenum Reduction to Molybdenum Blue in Serratia sp. Strain DRY5 Is Catalyzed by a Novel Molybdenum-Reducing Enzyme
}

\author{
M. Y. Shukor, ${ }^{1}$ M. I. E. Halmi, ${ }^{1}$ M. F. A. Rahman, ${ }^{1}$ N. A. Shamaan, ${ }^{2}$ and M. A. Syed ${ }^{1}$ \\ ${ }^{1}$ Department of Biochemistry, Faculty of Biotechnology and Biomolecular Sciences, Universiti Putra Malaysia (UPM), \\ 43400 Serdang, Selangor, Malaysia \\ ${ }^{2}$ Faculty of Medicine and Health Sciences, Universiti Sains Islam Malaysia, 13th Floor, Menara B, Persiaran MPAJ, \\ Jalan Pandan Utama, Pandan Indah, 55100 Kuala Lumpur, Malaysia
}

Correspondence should be addressed to M. Y. Shukor; mohdyunus@upm.edu.my

Received 22 July 2013; Revised 22 December 2013; Accepted 24 December 2013; Published 3 March 2014

Academic Editor: Muhammad I. Rajoka

Copyright (C) 2014 M. Y. Shukor et al. This is an open access article distributed under the Creative Commons Attribution License, which permits unrestricted use, distribution, and reproduction in any medium, provided the original work is properly cited.

\begin{abstract}
The first purification of the Mo-reducing enzyme from Serratia sp. strain DRY5 that is responsible for molybdenum reduction to molybdenum blue in the bacterium is reported. The monomeric enzyme has an apparent molecular weight of $105 \mathrm{kDalton}$. The isoelectric point of this enzyme was 7.55. The enzyme has an optimum $\mathrm{pH}$ of 6.0 and maximum activity between 25 and $35^{\circ} \mathrm{C}$. The Mo-reducing enzyme was extremely sensitive to temperatures above $50^{\circ} \mathrm{C}$ (between 54 and $70^{\circ} \mathrm{C}$ ). A plot of initial rates against substrate concentrations at $15 \mathrm{mM} 12-\mathrm{MP}$ registered a $V_{\max }$ for NADH at $12.0 \mathrm{nmole}$ Mo blue/min/mg protein. The apparent $K_{m}$ for $\mathrm{NADH}$ was $0.79 \mathrm{mM}$. At $5 \mathrm{mM} \mathrm{NADH}$, the apparent $V_{\max }$ and apparent $K_{m}$ values for $12-\mathrm{MP}$ of $12.05 \mathrm{nmole} / \mathrm{min} / \mathrm{mg}$ protein and $3.87 \mathrm{mM}$, respectively, were obtained. The catalytic efficiency $\left(k_{\mathrm{cat}} / K_{m}\right)$ of the Mo-reducing enzyme was $5.47 \mathrm{M}^{-1} \mathrm{~s}^{-1}$. The purification of this enzyme could probably help to solve the phenomenon of molybdenum reduction to molybdenum blue first reported in 1896 and would be useful for the understanding of the underlying mechanism in molybdenum bioremediation involving bioreduction.
\end{abstract}

\section{Introduction}

Microbes are at the forefront of heavy metals bioremediation due to their amazing ability to resist the inhibitory effects of heavy metals through a variety of mechanisms including bioprecipitation, extra- and intracellular sequestration, biosorption, bioreduction, transport mechanisms, and/or chelation [1].

One emerging global metal pollutant is molybdenum [2]. Microbial molybdenum reduction to molybdenum blue, a potential bioremediation tool, is a phenomenon that has been reported for over a century. According to Levine [3], microbial molybdate reduction to molybdenum blue was first mentioned in 1896 in E. coli [4]. Detailed studies on this phenomenon was only initiated in 1985 by Campbell et al. in E. coli $\mathrm{K} 12$ [5]. The reduction of molybdate into molybdenum blue by a chemolitotroph, Thiobacillus ferrooxidans (now
Acidithiobacillus ferrooxidans) strain AP19-3, was reported by Sugio et al. [6] without citing the works carried out by Campbell et al. [5]. This indicates the rarity of publications over this phenomenon. The first local bacterium reported with molybdenum-reducing ability is Enterobacter cloacae strain 48 (EC 48) [7]. A purification of the molybdenumreducing enzyme was attempted by Ariff et al. [8] but the activity is lost beyond the ammonium sulphate fraction. It was later discovered that the molybdenum blue produced from EC 48 and various other molybdenum-reducing bacteria exhibited a unique absorption spectra very similar to a reduced phosphomolybdate spectrum, thereby indicating that the intermediate species, phosphomolybdate, is involved [9-16]. Yong et al. [17] demonstrates that molybdenum reduction to molybdenum blue in Thiobacillus ferrooxidans is likely due to chemical action of ferrous irons supplemented in the medium. Up to this point, no method has yet been developed 
for distinguishing between genuine enzymatic and chemical reductions that has often plagued microbiological metalreduction phenomenon [18]. Fortunately, using a modified dialysis tubing method, the reduction of molybdenum to molybdenum blue in EC 48 and other molybdenum-reducing heterotrophic bacteria is demonstrated to be enzymatically linked [9-16, 18]. A novel enzyme assay using phosphomolybdate instead of molybdate was developed and a partial purification of the enzyme using ammonium sulphate precipitation, ion exchange, and gel filtration was attempted [19]. More recently, a better assay was constructed using laboratory-prepared phosphomolybdate [20] similar to the assay developed by Glenn and Crane [21]. In this work, the purification and characterisation of the Mo-reducing enzyme from Serratia sp. strain Dr.Y5 are here presented for the first time. It is hoped that this will increase the understanding of the outlying reduction mechanism of molybdenum to the nontoxic molybdenum blue in microbes that was reported as early as about 120 years ago.

\section{Methods}

2.1. Chemicals . All chemicals used were of analytical grade. Preparation of buffers was carried out at the appropriate temperatures by mixing the appropriate dibasic and basic salts.

2.2. Growth and Maintenance of Molybdate-Reducing Bacterium. The bacterium was isolated from the city of Taiping, Perak, Malaysia [14]. The bacterium was maintained on a solid agar of low phosphate $(2.9 \mathrm{mM}$ phosphate) media $(\mathrm{pH} 7.0)$ containing (w/v\%) sucrose (1\%), $\mathrm{MgSO}_{4} \cdot 7 \mathrm{H}_{2} \mathrm{O}$ (0.05\%), $\left(\mathrm{NH}_{4}\right)_{2} \mathrm{SO}_{4}(0.3 \%)$, yeast extract $(0.05 \%), \mathrm{NaCl}$ $(0.5 \%), \mathrm{Na}_{2} \mathrm{MoO}_{4} \cdot 2 \mathrm{H}_{2} \mathrm{O}(0.726 \%)$, and $\mathrm{Na}_{2} \mathrm{HPO}_{4}(0.073 \%)$. Sucrose was autoclaved separately. Growth in liquid media used $100 \mathrm{mM}$ phosphate instead.

2.3. Preparation of Crude Mo-Reducing Enzyme Fraction. The following experiment was carried out at $4^{\circ} \mathrm{C}$ unless stated otherwise. Cells of Serratia sp. strain DRY5 were harvested from a $5 \mathrm{~L}$ media $(100 \mathrm{mM}$ phosphate media) through centrifugation at $10000 \mathrm{~g}$ for 10 minutes after growth at $30^{\circ} \mathrm{C}$ for 24 hours on an orbital shaker at $100 \mathrm{rpm}$. Cells were resuspended with deionised water and centrifuged at $15000 \mathrm{~g}$ for 10 minutes. This process was repeated twice. The pellet was reconstituted with $50 \mathrm{~mL}$ of $50 \mathrm{mM}$ Tris- $\mathrm{HCl}$ buffer $\mathrm{pH} 7.5$ containing $0.5 \mathrm{mM}$ dithiothreitol and $0.1 \mathrm{mM}$ PMSF (phenylmethane-sulfonyl-fluoride). Cells were sonicated (Branson) on ice and then centrifuged at $15000 \mathrm{~g}$ for 20 minutes. Sonication was considered complete when little pellet was formed [19]. The supernatant is crude Serratia sp. strain DRY5 cell fraction. The crude fraction was subjected to ultracentrifugation for 2 hours at $105000 \mathrm{~g}$. The supernatant contains high Mo-reducing activity.

2.4. Enzyme Assay. The reaction mixture, $1 \mathrm{~mL}$, contained $3 \mathrm{mM}$ of 12-MP (electron acceptor substrate) in $50 \mathrm{mM}$ citrate phosphate buffer $\mathrm{pH} 5.0$ at room temperature and $100 \mu \mathrm{L}$ of NADH at the final concentration of $3 \mathrm{mM}$. Fifty microlitres of enzyme fraction containing about $1 \mathrm{mg}$ protein was added to start the reaction. The absorbance increase in one minute was read at $865 \mathrm{~nm}$. One unit of Mo-reducing enzyme activity is defined as the amount of enzyme that produces 1 nmole molybdenum blue measured as equivalent to ascorbate-reduced $12-\mathrm{MP}$ in one minute at room temperature. The molar absorptivity or extinction coefficient at $865 \mathrm{~nm}$ for molybdenum blue using 12-MP as a standard is $16.7 \mathrm{mM} \mathrm{m}^{-1} \cdot \mathrm{cm}^{-1}$. An increase in 1.00 unit absorbance per minute at OD $865 \mathrm{~nm}$ of per $\mathrm{mg}$ protein would yield 60 units of enzyme activity or 60 nmole of 12-MP in a $1 \mathrm{~mL}$ assay mixture [20].

\subsection{Ion-Exchange Chromatography Using Mono-Q Strong-} Anion Exchanger. Although ammonium sulphate gave good purification and yield in the purification attempt of Moreducing enzyme from EC 48 [19], preliminary results show that it gave no advantage in purification fold (3-fold) and also gave poor recovery $(<50 \%)$. All experiments were carried out at $4^{\circ} \mathrm{C}$ unless stated otherwise. Thus, crude fraction (cytoplasmic fraction after ultracentrifuge) was subjected straight to ion exchange. The crude fraction was subjected to the strong-anion exchange matrix Mono Q (Amersham Pharmacia). The Mono-Q 5/50 GL Tricorn column (maximum tolerable pressure of $50 \mathrm{Bar}$ ) was connected to a modified Agilent 1100 Series high performance liquid chromatography (HPLC) unit. A makeshift cooling system consisting of a $4^{\circ} \mathrm{C}$ chilled circulating water through silicon tubing system was developed to cool the column. The original HPLC loop and tubings were replaced with polyetheretherketone (PEEK) tubings. The column was first washed with $5 \mathrm{mLs}$ of $1 \mathrm{M}$ $\mathrm{NaCl}$ in buffer A followed by washing with $200 \mathrm{~mL}$ of buffer A until the eluant $\mathrm{pH}$ is 7.5 . About 40 milligrams of the crude enzyme in $2 \mathrm{mLs}$ of volume was injected into Rheodyne sample injector to load the Mono-Q column at a flow rate of $1 \mathrm{~mL}$ per minute and then washed with the same buffer until the signal for protein content, measurable at $280 \mathrm{~nm}$, became undetected. The washed eluant was collected using a fraction collector at $1 \mathrm{~mL}$ per tube and assayed for enzyme activity. Enzyme was eluted from the column with a linear gradient of $0-0.5 \mathrm{M} \mathrm{KCl}$ in buffer $\mathrm{A}$ at the flow rate of

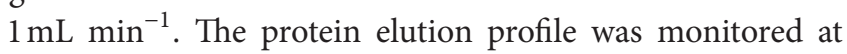
$280 \mathrm{~nm}$.

The fractions showing enzyme activity were pooled and assayed for protein and enzyme activity. The pooled enzyme was dialyzed against $5 \mathrm{~L}$ of $10 \mathrm{mM}$ Tris. $\mathrm{Cl} \mathrm{pH} 7.5$ containing $0.5 \mathrm{mM}$ dithiothreitol for 5 hours. The dialysed fraction was centrifuged at $15000 \mathrm{~g}$ to remove precipitated fraction and the supernatant applied again to Mono Q and purification of the enzyme was carried out as before. Protein was quantified according to the method of Bradford [22] using BSA as the standard. The dialyzed enzyme was then concentrated using a cellulose triacetate filter membrane with a molecular weight cut-off point of $10 \mathrm{kDa}$ in an Amicon ultrafiltration cell at $4^{\circ} \mathrm{C}$ to a final volume of $0.5 \mathrm{~mL}$. One hundred microlitres of sample was applied into Zorbax GFC-250 column $(250 \times$ $9.4 \mathrm{~mm}$ ) and eluted using buffer A containing 0.2 M KCL at 
TABLE 1: Partial purification scheme of Mo-reducing enzyme from Serratia sp. strain DRY5.

\begin{tabular}{lccccc}
\hline Fraction & Total protein $(\mathrm{mg})$ & Specific activity (units/mg protein) & Total activity (units) & Yield \% & Fold purification \\
\hline Crude & 500 & 3 & 1500 & 100.0 & 1.0 \\
Mono Q & 120 & 11.5 & 1380 & 92 & 3.8 \\
Mono Q $^{*}$ & 10 & 17.5 & 175 & 11.66 & 5.8 \\
Zorbax GF-250 & 1.2 & 24.3 & 29.16 & 1.9 & 8.1 \\
Chromatofocusing & 0.1 & 0.25 & 0.25 & 0.0002 & 0.08 \\
\hline
\end{tabular}

a flow rate of $0.5 \mathrm{~mL} \mathrm{~min}{ }^{-1}$. The purified fraction was used for kinetic studies.

2.6. Determination of Kinetic Parameter. Michaelis menten kinetics constants were determined using GraphPad prism nonlinear regression analysis available from http://www .graphpad.com/.

2.7. Molecular Mass Determination. Estimation of the native molecular weight of the Mo-reducing enzyme was carried out using gel filtration on Zorbax GF-250 precalibrated with gel filtration molecular weight markers (Bio Rad) and the subunit $\mathrm{Mr}$ was determined using SDS-PAGE. Broad range protein standard marker (BioRAd) (myosin $(200 \mathrm{kD}), \beta$ galactosidase $(116.25 \mathrm{kD})$, bovine serum albumin $(66.2 \mathrm{kD})$, phosphorylase b $(97.4 \mathrm{kD})$, ovalbumin $(45 \mathrm{kD})$, soybean trypsin inhibitor $(21.5 \mathrm{kD})$, carbonic anhydrase $(31 \mathrm{kD})$, aprotinin $(6.5 \mathrm{kD})$, and lysozyme $(14.4 \mathrm{kD}))$ were used to determine the molecular weight of the protein. Proteins in the gels were detected with silver staining [23].

2.8. Estimation of the Isoelectric Point (pI). The $\mathrm{pI}$ of the enzyme was estimated by chromatofocusing on Mono P 5/200 GL Tricorn column (Pharmacia Biotech) anion exchange column attached to an Agilent 1100 series. This was equilibrated with $25 \mathrm{mM}$ diethanolamine $\mathrm{pH} 9.5$ containing $0.5 \mathrm{mM}$ dithiothreitol until the eluant has a $\mathrm{pH}$ of 9.5. The column was eluted (pregradient) with $9 \mathrm{~mL}$ of an isocratic gradient of $10 \%$ (v/v) Polybuffer 96 adjusted to $\mathrm{pH} 6.0$ with $\mathrm{HCl}$ before sample was injected into the column and eluted using the same buffer [24].

\section{Results and Discussion}

3.1. Purification of Mo-Reducing Enzyme. The fraction containing enzyme activity elutes at tube number 19 to 20 at about $330 \mathrm{mM} \mathrm{NaCl}$ (Figure 1). This fraction was pooled, dialysed, and rechromatographed again on Mono Q. The results show more improvement in terms of the separation of Mo-reducing enzyme from the enzyme eluting as a single peak at tube number 26 at $300 \mathrm{mM} \mathrm{NaCl}$ (Figure 2). A single peak was also seen on gel filtration when the fraction with Mo-reducing enzyme activity from the second ion exchange was applied to Zorbax GF-250 (Figure 3). An 8.1-fold purification was achieved after gel filtration. A 40-fold partial purification was achieved after gel filtration on Sephadex G-200 in EC 48. The apparent molecular weight for the Mo-reducing enzyme as estimated from gel filtration was 105 KDalton. Native-PAGE

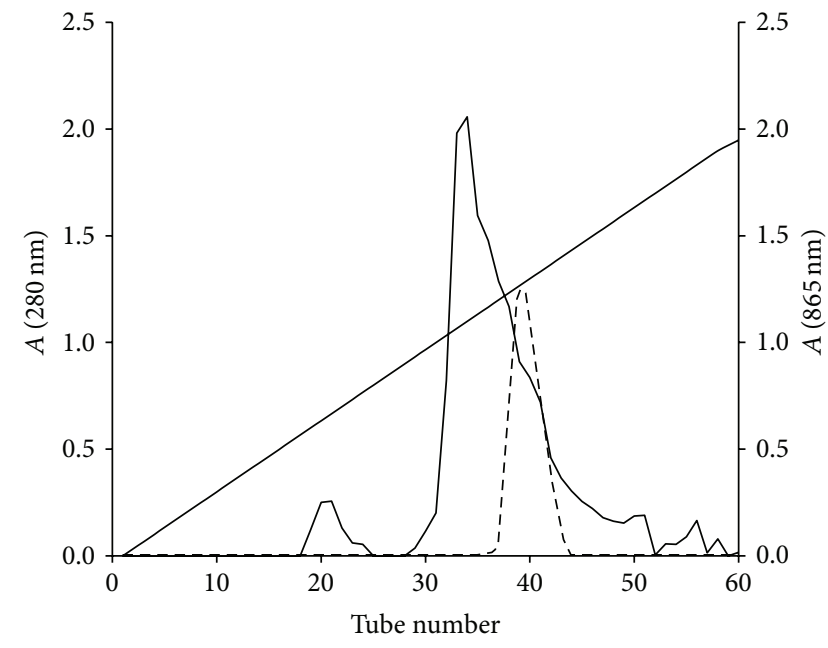

FIgURE 1: Ion exchange on Mono Q. Elution profile of protein (- - -) and enzyme activity (-). Diagonal line represents salt $(\mathrm{NaCl})$ gradient ( 0 to $0.5 \mathrm{M})$.

analysis revealed that the presence of only a single band near (data not shown) while denaturing SDS-PAGE shows a single band at $100 \mathrm{KDa}$ (Figure 4). Together with the gel filtration results, it can be concluded that the Mo-reducing enzyme was monomeric. Table 1 shows that ion exchange chromatography removes much of the enzyme activity. This results in a markedly reduced yield. The isoelectric point of this enzyme was determined to be 7.55 using Mono $\mathrm{P}$ chromatofocusing. Several attempts to purify the Moreducing enzyme from EC 48 have resulted in failure due to the problematic assay system $[7,8]$ and to the problematic ion exchange step [19].

The ion exchange stage removes much of enzyme activity but the method was vital in the purification strategy. The same effect was also observed during the purification of the enzyme from EC 48. Probably, a soluble coenzyme was removed during adsorption to the exchanger. In the foreseeable future, other chromatographic techniques and studies on the effects of possible cofactors or coenzymes will be carried out to address this issue. A partial purification of the enzyme from EC 48 showed three protein bands with the molecular weights of 80,90 and $100 \mathrm{kDa}$ [19]. The purification step using Mono $\mathrm{P}$ showed no improvement in the purification fold and the yield was very poor. Probably, the enzyme was no longer stable after gel filtration. 


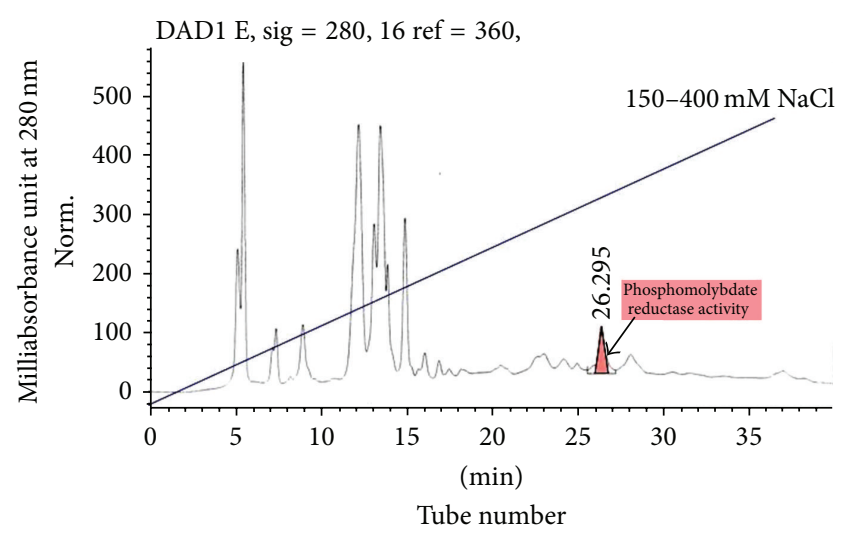

FIgURE 2: Second ion exchange of Mo-reducing enzyme on Mono $\mathrm{Q}$ on an Agilent 1100 series. Shaded region indicates Mo-reducing enzyme activity.

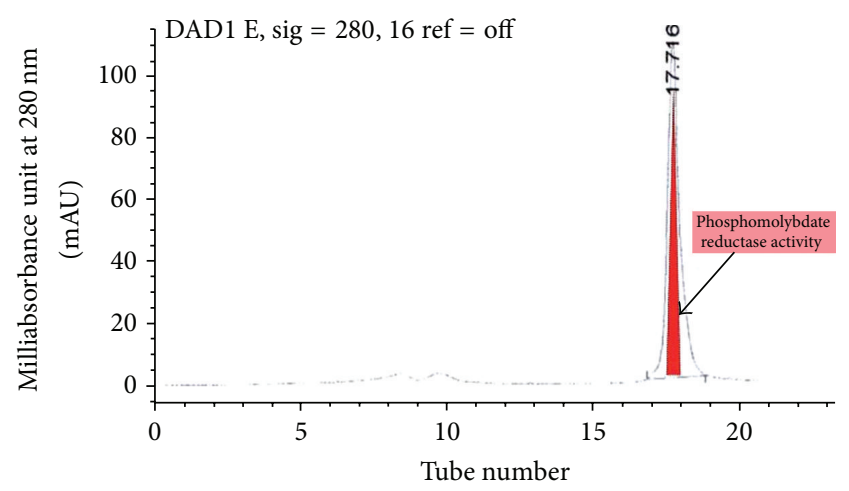

FIGURE 3: Gel filtration on Zorbax GFC-250. Shaded region indicates Mo-reducing enzyme activity. Each tube number or fraction represents $0.5 \mathrm{~mL}$.

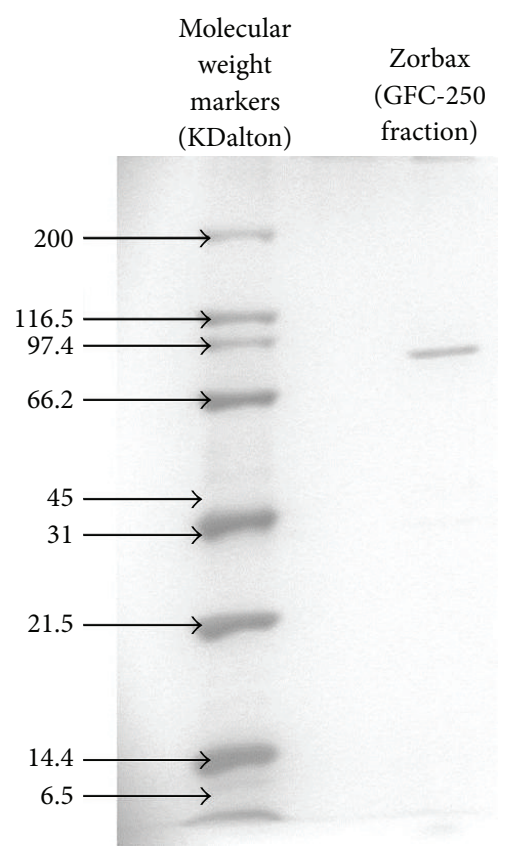

FIGURE 4: SDS-PAGE electrophoretogram of purified Mo-reducing enzyme stained by silver staining method.
Phosphomolybdate reduction to molybdenum blue by enzymatic reaction has previously been reported, catalysed by xanthine and aldehyde oxidase [21], although preliminary results using xanthine and formaldehyde (or acetaldehyde as an electron donor substrates) did not yield Mo-blue in this bacterium, indicating that a different enzyme is responsible. This is the first report on the purification of an enzyme responsible for the physiological molybdate reduction seen in microbes.

To date, the enzyme responsible for the Mo-reducing activity in EC 48 or any other bacterium has never been successfully purified to homogeneity.

The only known enzyme which could reduce molybdate is molybdate reductase [25]. The enzyme catalyses the reduction of $\mathrm{Mo}(6+)$ to the (4+) oxidation state before its integration with the sulphur atoms of a pterin derivative named molybdopterin, cofactor of molybdoenzymes. During the enzyme-catalysed reaction, the oxidation state of molybdenum changes so that molybdenum is involved in the electron-transfer pathway. Molybdenum cofactor-containing enzymes catalyse the transfer of an oxygen atom, ultimately derived from or incorporated into water, to or from a substrate in a two-electron redox reaction [26]. The reduction of molybdate to the $4+$ oxidation state is not accompanied by a change in colour. The oxidation state of molybdenum blue is, however, quite complex. Electron spin resonance (esr) work showed that the reducing agent dithionite donates two electrons to a heteropolymolybdate, $\mathrm{PMo}_{12} \mathrm{O}_{40}{ }^{3-}$ (12molybdophosphate), producing Mo-blue. The introduced electrons were found to be uniformly dispersed over the whole polymetallate sphere by a process involving thermal activation hopping. The electrons in the two-electron reduced forms were very mobile as shown by ${ }^{17} \mathrm{O}$ nuclear magnetic resonance (nmr) spectroscopy. This results in the averaging of the valence of all the twelve molybdenum atoms [27]. This explains the resultant mixed valence (between $5+$ and $6+$ ) properties of Mo-blue [28].

3.2. Optimum $p H$. The activity of the purified enzyme was measured at various $\mathrm{pH}$ values ranging between 4.0 and 9.0. As shown in Figure 5, maximum activity was obtained at $\mathrm{pH}$ 6.0. In contrast, Mo-reducing activity in EC 48 occurs optimally at pH 5.0 [19]. It has been reported that formation of 12-MP and heteropolymolybdates, in general, requires an acidic environment and that $12-\mathrm{MP}$ is unstable at neutral $\mathrm{pH}$ [28]. This could explain the low optimum $\mathrm{pH}$ for the reaction of the enzyme on 12-MP for both bacteria, since the substrate is not stable at neutral and higher $\mathrm{pH}$. The lower activity exhibited by phosphate buffer is possibly due to the effect of phosphate on phosphomolybdate instability [18].

3.3. Optimum Temperature. To determine the optimum temperature for enzyme activity, reactions were performed at various temperatures $\left(20-70^{\circ} \mathrm{C}\right)$ at $\mathrm{pH} 6.0$ for $1 \mathrm{~h}$. The Moreducing enzyme showed maximum activity in between 25 and $35^{\circ} \mathrm{C}$ (Figure 6) similar to the optimum temperature range reported for EC $48\left(28-33^{\circ} \mathrm{C}\right)$ [19]. The activity drastically dropped at higher temperatures and no activity 


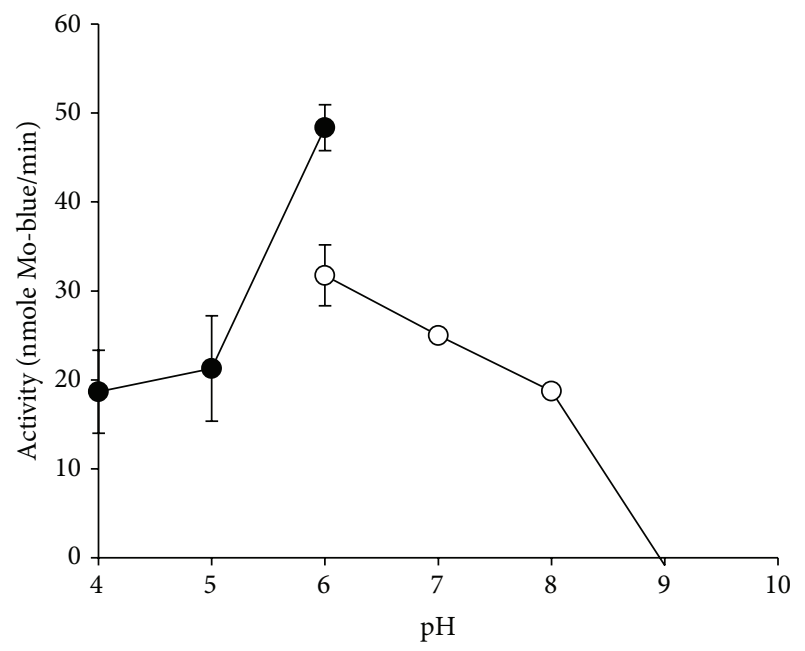

FIGURE 5: Effect of pH on enzyme activity using an overlapping buffer system consisting of citrate $(\bullet)$ and phosphate $(\bigcirc)$ buffers. Error bars are mean \pm standard deviation of triplicates.

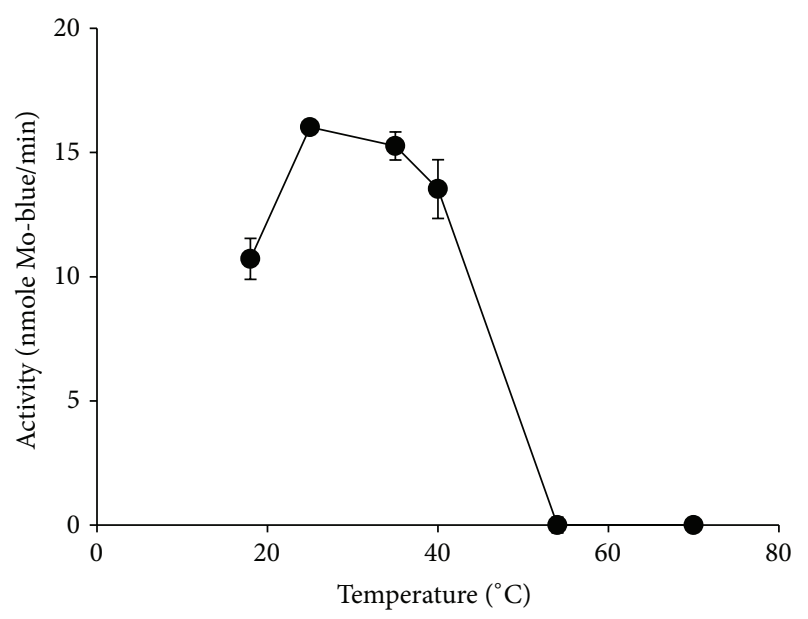

FIGURE 6: Effect of temperature on enzyme activity. Error bars are mean \pm standard deviation of triplicates.

was detected higher than $50^{\circ} \mathrm{C}$. The profile of optimum temperature fits well for most mesophilic bacterium with activity ranges from 20 to $40^{\circ} \mathrm{C}$.

3.4. Temperature Stability Studies. Mo-reducing enzyme was extremely sensitive to temperatures above $50^{\circ} \mathrm{C}$ (54 and $70^{\circ} \mathrm{C}$ ) as evident from Figure 7 with total loss of activity occurring after 30 minutes of preincubation. Other preincubation temperatures $\left(25\right.$ to $40^{\circ} \mathrm{C}$ ) caused $80 \%$ loss of enzyme activity after 15 hours of incubation (Data not shown). The instability of enzymes at high temperature is caused by several factors including tertiary and quaternary protein denaturation through thermal vibration leading to loss of cofactors, contaminating protease (from handling) with accelerated activity at higher temperatures, and accelerated oxidation of sulfhydryl groups at higher temperatures to name a few [19].

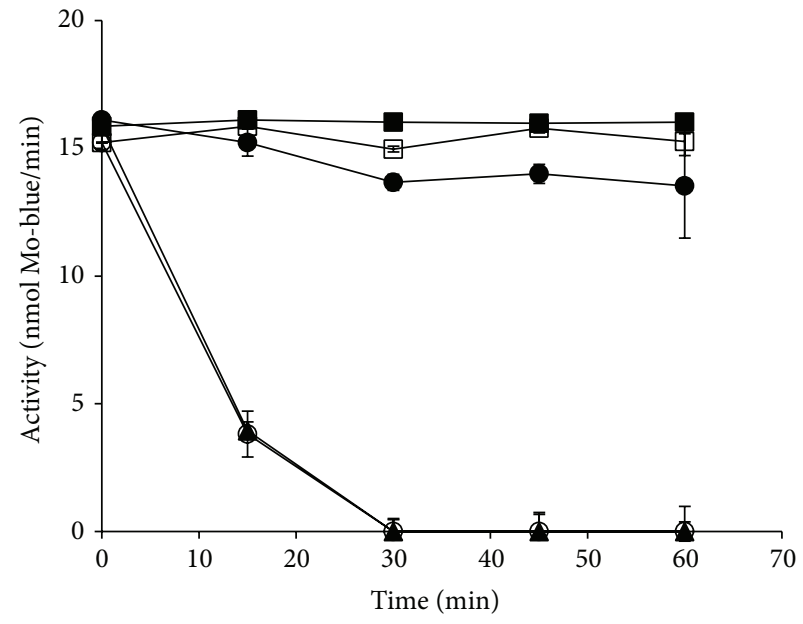

Figure 7: The effects of preincubation temperatures of $25^{\circ} \mathrm{C}(\boldsymbol{\square})$, $34^{\circ} \mathrm{C}(\square), 40^{\circ} \mathrm{C}(\bullet), 54^{\circ} \mathrm{C}(\boldsymbol{\Delta})$, and $70^{\circ} \mathrm{C}(\bigcirc)$ on the stability of the enzyme. Error bars are mean \pm standard deviation of triplicates.

3.5. $p H$ Stability Studies. Figure 8 shows that the Moreducing enzyme was relatively unstable at all of the preincubated $\mathrm{pH}$ studied after 10 hours of incubation on ice with a lowering of activity of up to $50 \%$ at all incubation pHs. Acidic preincubation $\mathrm{pH}(\mathrm{pH} 4$ and 5) causes the most damage with total loss of activity after 10 hours. Moreducing enzyme is most stable at $\mathrm{pH}$ 6.0. This instability is probably the main reason why a large loss of activity was seen during chromatography where the temperature could reach as high as $10^{\circ} \mathrm{C}$ especially during transfer and handling. The composite effect is a reduction of activity not due to proteases of loss of cofactor but due to the instability of the enzyme itself. The most useful buffer at this $\mathrm{pH}$ for storage was citrate (pKa 5.0) at pH 6.0 although phosphate ( $\mathrm{pKa}$ 6.8) can be used but only at lower molarities $(<20 \mathrm{mM})$ since it is known to destabilize phosphomolybdate when present in the reaction mixture [21].

Enzymes, being amphoteric molecules, contain on their surface a large number of basic and acidic groups. The charges on these basic and acidic groups vary according to their dissociation constants that vary with the $\mathrm{pH}$ of the environment. Changes in $\mathrm{pH}$ will affect the distribution of charges on their exterior surfaces and hence the total net charge of the enzymes. This in turn affects the reactivity of the catalytic active groups. During assay, change in $\mathrm{pH}$ of the environment would change the ionic state of the catalytic groups especially in the active sites. This will render usually unfavorable binding to the substrate(s) in the extreme conditions. This is the cause of enzymes having a $\mathrm{pH}$ profile in accordance with the optimum and inactivation $\mathrm{pH}$ range. In the case of stability, as in this study, changes in charges could be permanent after prolonged storage in unfavorable $\mathrm{pH}$ or buffer species and will affect the structural stability and solubility of the enzyme, leading towards inactivity or denaturation of the enzyme. 


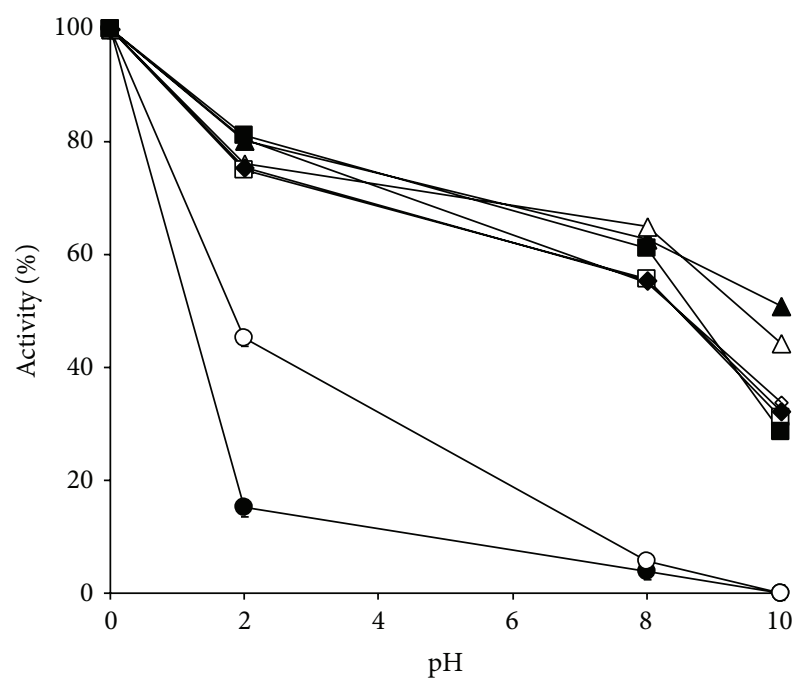

Figure 8: The effects of preincubation pHs of $4(\bullet), 5(\bigcirc), 6(\mathbf{\Delta}), 7$ $(\triangle), 7.5(\diamond), 8(\square), 9(\mathbf{\square})$, and $10(\bullet)$ on the stability of the Mo-reducing enzyme. The enzyme was preincubated at different $\mathrm{pHs}$ on ice before assay. Error bars are mean \pm standard deviation of triplicates.

3.6. Determination of Kinetic Parameter. Preliminary results show that $15 \mathrm{mM} 12$-MP were saturating. A plot of initial rates against substrate concentrations at $15 \mathrm{mM} 12-\mathrm{MP}$ registered a $V_{\max }$ for $\mathrm{NADH}$ at $12.0 \mathrm{nmole}$ Mo blue/min/mg protein. The model giving the best regression coefficient $(0.99)$ was one phase binding. The apparent $K_{m}$ for NADH was $0.79 \mathrm{mM}$.

At $5 \mathrm{mM} \mathrm{NADH}$, the apparent $V_{\max }$ and apparent $K_{m}$ values for $12-\mathrm{MP}$ of $12.05 \mathrm{nmole} / \mathrm{min} / \mathrm{mg}$ protein and $3.87 \mathrm{mM}$, respectively, were obtained. The $V_{\max }$ for NADH reported in this work is higher than EC 48's Mo-reducing enzyme at $6.28 \mathrm{nmole}$ Mo blue $/ \mathrm{min} / \mathrm{mg}$ protein [19] while the apparent $K_{m}$ for NADH was lower than EC 48 at $1.65 \mathrm{mM}$, suggesting a higher affinity to the Mo-reducing enzyme in strain Dr.Y5. A similar apparent $V_{\max }$ values for the electron accepting substrate, 12-MP were obtained but a higher apparent $K_{m}$ for this substrate compared to $0.32 \mathrm{mM}$ for EC 48 's Moreducing enzyme [19] suggests that the enzyme from EC 48 has a higher affinity to $12-\mathrm{MP}$ compared to this strain. The catalytic efficiency $\left(k_{\mathrm{cat}} / K_{m}\right)$ of the Mo-reducing enzyme was $5.47 \mathrm{M}^{-1} \mathrm{~s}^{-1}$. The catalytic efficiency is about 200,000 -fold less efficient than the most catalytically efficient chromate reductase, a similarly related metal reductase, isolated from Thermus scotoductus [29]. The similarity and difference seen in this work reflect the unique nature of Mo-reducing enzyme from different bacteria.

3.7. Effects of Metal Ions and Stability Compounds. The addition of EDTA was inhibitory to the enzyme activity while the sulfhydryl protective agents such as DTT and 2mercaptoethanol increase activity at $1 \mathrm{mM}$ and were strongly inhibitory at $5 \mathrm{mM}$ (Table 2). The effect of metal ions shows that both lead and copper inhibited the enzyme (Table 3). The Mo-reducing enzyme probably contains metals cofactor as evident from the effect of EDTA. The enzyme also probably contains the sulfhydryl group since the addition of sulfhydryl
TABLE 2: Effect of denaturants and stabilising agents on activity of Mo-reducing enzyme from Serratia sp. strain DRY5.

\begin{tabular}{lcc}
\hline Compounds & $\begin{array}{c}\text { Concentrations } \\
\text { which decrease } \\
\text { enzyme activity by } \\
50 \%\end{array}$ & $\begin{array}{c}\text { Concentrations } \\
\text { which increase } \\
\text { enzyme activity by } \\
50 \%\end{array}$ \\
\hline EDTA & $0.1 \mathrm{mM}$ & - \\
Triton x-100 & $0.1 \%$ & - \\
SDS & $0.1 \%$ & - \\
Ethylene glycol & $>10 \%$ & - \\
Ethanol & $>10 \%$ & - \\
Acetone & $>10 \%$ & - \\
DTT & $10 \mathrm{mM}$ & $1 \mathrm{mM}$ \\
2-Mercaptoethanol & $5 \mathrm{mM}$ & $1 \mathrm{mM}$ \\
\hline
\end{tabular}

TABLE 3: Effect of metal salts $(0.01 \mathrm{mM})$ on activity of Mo-reducing enzyme of Serratia sp. strain DRY5.

\begin{tabular}{lc}
\hline Metals & Relative activity $(\%) \pm$ standard deviation $(n=3)$ \\
\hline Control & $101.07 \pm 2.10$ \\
$\mathrm{Ni}$ & $103.86 \pm 2.51$ \\
$\mathrm{Ag}$ & $103.25 \pm 5.19$ \\
$\mathrm{Co}$ & $103.11 \pm 2.83$ \\
$\mathrm{Cd}$ & $102.30 \pm 2.79$ \\
$\mathrm{~W}$ & $102.22 \pm 6.28$ \\
$\mathrm{Zn}$ & $101.61 \pm 3.71$ \\
$\mathrm{Al}$ & $101.61 \pm 2.59$ \\
$\mathrm{Cr}$ & $101.47 \pm 3.96$ \\
$\mathrm{Cs}$ & $101.32 \pm 5.15$ \\
$\mathrm{As}$ & $101.07 \pm 6.57$ \\
$\mathrm{Li}$ & $98.30 \pm 4.89$ \\
$\mathrm{Se}$ & $97.38 \pm 2.30$ \\
$\mathrm{Bo}$ & $96.89 \pm 2.12$ \\
$\mathrm{Hg}$ & $96.83 \pm 2.55$ \\
$\mathrm{Ba}$ & $93.84 \pm 2.83$ \\
$\mathrm{Mn}$ & $92.34 \pm 10.77$ \\
$\mathrm{~Pb}$ & $61.93 \pm 25.35$ \\
$\mathrm{Cu}$ & $23.32 \pm 1.55$ \\
\hline
\end{tabular}

protective agents such as DTT and 2-mercaptoethanol increases activity. The inhibitory effect of copper on the Mo-reducing enzyme is also demonstrated in all recently isolated Mo-reducing bacteria [9-16] and in other heavy metals-reducing bacteria works such as chromium $[30,31]$ and mercury [32]. It is known that copper binds itself to the sulfhydryl group of enzymes [26] and this is probably the likely scenario in this enzyme.

\section{Conclusion}

In this work, the purification of the Mo-reducing activity is reported using a combination of ion exchange and gel filtration. Since its first report in E. coli in 1896, the Moreducing enzyme that is responsible for the molybdenum 
blue phenomenon has never been purified. However, work in this area is yet to be completed. The enzyme yield is such that it is not possible to do N-terminal sequencing. Thus, works are currently being carried out to maximize the yield. If the sequencing results showed novel characteristics, then the Mo-reducing enzyme should have a new name, $\mathrm{NAD}(\mathrm{P}) \mathrm{H}$ : phosphomolybdate oxidoreductase or, simply, phosphomolybdate reductase. The greater understanding of the underlying mechanism of molybdenum reduction catalyzed by this enzyme could lead to improved processes in the area of bioremediation [33], reducing biocorrosion [34], biomining [35], and biorecycling of molybdenum [36, 37].

\section{Conflict of Interests}

The authors declare that there is no conflict of interests regarding the publication of this paper.

\section{Acknowledgment}

This project was supported by funds from The Research University Grant Scheme (RUGS), Universiti Putra Malaysia, Project no. 05-01-09-0750RU/F1.

\section{References}

[1] M. E. Mahmoud, M. M. Osman, S. B. Ahmed, and T. M. AbdelFattah, "Enhanced removal of lead by chemically and biologically treated carbonaceous materials," The Scientific World Journal, vol. 2012, Article ID 604198, 11 pages, 2012.

[2] G. K. Davis, "Molybdenum," in Metals and Their Compounds in the Environment, Occurrence, Analysis and Biological Relevance, E. Merian, Ed., pp. 1089-1100, Wiley-VCH, New York, NY, USA, 1991.

[3] V. E. Levine, "The reducing properties of microorganisms with special reference to selenium compounds," Journal of Bacteriology, vol. 10, no. 3, pp. 217-263, 1925.

[4] A. Capaldi and B. Proskauer, "Beiträge zur kenntniss der säurebildung bei typhus-bacillen und bacterium coli," Zeitschrift für Hygiene und Infectionskrankheiten, vol. 23, no. 3, pp. 452-474, 1896.

[5] A. M. Campbell, A. del Campillo-Campbell, and D. B. Villaret, "Molybdate reduction by Escherichia coli K-12 and its chl mutants," Proceedings of the National Academy of Sciences of the United States of America, vol. 82, no. 1, pp. 227-231, 1985.

[6] T. Sugio, Y. Tsujita, T. Katagiri, K. Inagaki, and T. Tano, "Reduction of $\mathrm{Mo}^{6+}$ with elemental sulfur by Thiobacillus ferrooxidans," Journal of Bacteriology, vol. 170, no. 12, pp. 5956-5959, 1988.

[7] B. Ghani, M. Takai, N. Z. Hisham et al., "Isolation and characterization of $\mathrm{a} \mathrm{Mo}^{6+}$-reducing bacterium," Applied and Environmental Microbiology, vol. 59, no. 4, pp. 1176-1180, 1993.

[8] A. B. Ariff, M. Rosfarizan, B. Ghani, T. Sugio, and M. I. A. Karim, "Mo-reducing enzyme in Enterobacter cloacae strain 48," World Journal of Microbiology and Biotechnology, vol. 13, no. 6, pp. 643-647, 1997.

[9] M. Y. Shukor, S. H. M. Habib, M. F. A. Rahman et al., "Hexavalent molybdenum reduction to molybdenum blue by $S$. Marcescens strain Dr. Y6," Applied Biochemistry and Biotechnology, vol. 149, no. 1, pp. 33-43, 2008.
[10] M. Y. Shukor, M. F. Rahman, Z. Suhaili, N. A. Shamaan, and M. A. Syed, "Bacterial reduction of hexavalent molybdenum to molybdenum blue," World Journal of Microbiology and Biotechnology, vol. 25, no. 7, pp. 1225-1234, 2009.

[11] M. Y. Shukor, M. F. Rahman, N. A. Shamaan, and M. S. Syed, "Reduction of molybdate to molybdenum blue by Enterobacter sp. strain Dr.Y13," Journal of Basic Microbiology, vol. 49, supplement 1, pp. S43-S54, 2009.

[12] S. M. Yunus, H. M. Hamim, O. M. Anas, S. N. Aripin, and S. M. Arif, "Mo (VI) reduction to molybdenum blue by Serratia marcescens strain Dr. Y9," Polish Journal of Microbiology, vol. 58, no. 2, pp. 141-147, 2009.

[13] M. F. A. Rahman, M. Y. Shukor, Z. Suhaili, S. Mustafa, N. A. Shamaan, and M. A. Syed, "Reduction of Mo(VI) by the bacterium Serratia sp. strain DRY5," Journal of Environmental Biology, vol. 30, no. 1, pp. 65-72, 2009.

[14] M. Y. Shukor, M. F. Rahman, Z. Suhaili, N. A. Shamaan, and M. A. Syed, "Hexavalent molybdenum reduction to Mo-blue by Acinetobacter calcoaceticus," Folia Microbiologica, vol. 55, no. 2, pp. 137-143, 2010.

[15] M. Y. Shukor, S. A. Ahmad, M. M. M. Nadzir, M. P. Abdullah, N. A. Shamaan, and M. A. Syed, "Molybdate reduction by Pseudomonas sp. strain DRY2," Journal of Applied Microbiology, vol. 108, no. 6, pp. 2050-2058, 2010.

[16] H. K. Lim, M. A. Syed, and M. Y. Shukor, "Reduction of molybdate to molybdenum blue by Klebsiella sp. strain hkeem," Journal of Basic Microbiology, vol. 52, no. 3, pp. 296-305, 2012.

[17] N. K. Yong, M. Oshima, R. C. Blake II, and T. Sugio, "Isolation and some properties of an iron-oxidizing bacterium Thiobacillus ferrooxidans resistant to molybdenum ion," Bioscience, Biotechnology and Biochemistry, vol. 61, no. 9, pp. 1523-1526, 1997.

[18] M. Y. Shukor, M. A. Syed, C. H. Lee, M. I. A. Karim, and N. A. Shamaan, "A method to distinguish between chemical and enzymatic reduction of molybdenum in Enterobacter cloacae strain 48," Malaysian Journal of Biochemistry, vol. 7, pp. 71-72, 2002.

[19] M. Y. Shukor, N. A. Shamaan, M. A. Syed, C. H. Lee, and M. I. A. Karim, "Characterization and quantification of molybdenum blue production in Enterobacter cloacae strain 48 using 12molybdophosphate as the reference compound," Asia Pacific Journal of Molecular Biology and Biotechnology, vol. 8, no. 2, pp. 167-172, 2000.

[20] M. Y. Shukor, S. H. M. Habib, M. F. A. Rahman et al., "Hexavalent molybdenum reduction to molybdenum blue by $S$. Marcescens strain Dr. Y6," Applied Biochemistry and Biotechnology, vol. 149, no. 1, pp. 33-43, 2008.

[21] J. L. Glenn and F. L. Crane, "Studies on metalloflavoproteins: V. The action of silicomolybdate in the reduction of cytochrome $c$ by aldehyde oxidase," Biochimica et Biophysica Acta, vol. 22, no. 1, pp. 111-115, 1956.

[22] M. M. Bradford, "A rapid and sensitive method for the quantitation of microgram quantities of protein utilizing the principle of protein dye binding," Analytical Biochemistry, vol. 72, no. 1-2, pp. 248-254, 1976.

[23] H. H. Blum, H. Beier, and R. Dernick, "Simplified method for silver staining of proteins in polyacrylamide gels and the mechanism of silver staining," Electrophoresis, vol. 8, pp. 93-99, 1987.

[24] T. J. Mantle and P. Noone, "Chromatofocusing," in Protein Purification Protocols, S. Doonan, Ed., pp. 249-254, Humana Press, Totowa, NJ, USA, 1999. 
[25] B. Frey, G. Janel, U. Michelsen, and H. Kersten, "Mutations in the Escherichia coli fnr and tgt genes: control of molybdate reductase activity and the cytochrome d complex by fnr," Journal of Bacteriology, vol. 171, no. 3, pp. 1524-1530, 1989.

[26] C. Kisker, H. Schindelin, and D. C. Rees, "Molybdenumcofactor-containing enzymes: structure and mechanism," Annual Review of Biochemistry, vol. 66, pp. 233-267, 1997.

[27] L. P. Kazansky and M. A. Fedotov, "Phosphorus" ${ }^{-31}$ and oxygen $^{-17}$ N.M.R. evidence of trapped electrons in reduced 18molybdodiphosphate $(\mathrm{V}), \mathrm{P}_{2} \mathrm{Mo}_{18} \mathrm{O}_{6}^{28-}$," Journal of the Chemical Society, Chemical Communications, no. 13, pp. 644-647, 1980.

[28] N. V. Sidgwick, The Chemical Elements and Their Compounds, Clarendon Press, Oxford, UK, 1984.

[29] D. J. Opperman, L. A. Piater, and E. van Heerden, "A novel chromate reductase from Thermus scotoductus SA-01 related to old yellow enzyme," Journal of Bacteriology, vol. 190, no. 8, pp. 3076-3082, 2008.

[30] R. Elangovan, L. Philip, and K. Chandraraj, "Hexavalent chromium reduction by free and immobilized cell-free extract of Arthrobacter rhombi-RE," Applied Biochemistry and Biotechnology, vol. 160, no. 1, pp. 81-97, 2010.

[31] U. Thacker and D. Madamwar, "Reduction of toxic chromium and partial localization of chromium reductase activity in bacterial isolate DM1," World Journal of Microbiology and Biotechnology, vol. 21, no. 6-7, pp. 891-899, 2005.

[32] J. E. Booth and J. W. Williams, "The isolation of a mercuric ionreducing flavoprotein from Thiobacillus ferrooxidans," Journal of General Microbiology, vol. 130, no. 3, pp. 725-730, 1984.

[33] N. Jafari and Z. Senobari, "Removal of $\mathrm{Pb}$ (II) ions from aqueous solutions by Cladophora rivularis (Linnaeus) hoek," The Scientific World Journal, vol. 2012, Article ID 793606, 6 pages, 2012.

[34] T. M. P. Nguyen, X. Sheng, Y.-P. Ting, and S. O. Pehkonen, "Biocorrosion of AISI 304 stainless steel by Desulfo vibrio desulfuricans in seawater," Industrial and Engineering Chemistry Research, vol. 47, no. 14, pp. 4703-4711, 2008.

[35] C. Hödar, P. Moreno, A. di Genova et al., "Genome wide identification of Acidithiobacillus ferrooxidans (ATCC 23270) transcription factors and comparative analysis of ArsR and MerR metal regulators," BioMetals, vol. 25, no. 1, pp. 75-93, 2012.

[36] A. S. Vieux, N. Rutagengwa, and V. Noki, "Extraction of molybdenum (VI) from hydrochloric acid solutions by triisooctylamine in organic diluents," Inorganic Chemistry, vol. 15, no. 3, pp. 722-725, 1976.

[37] E. A. J. Al-Mulla, N. A. B. Ibrahim, K. Shameli, M. B. Ahmad, and W. M. Z. W. Yunus, "Extraction of molybdenum (VI) from hydrochloric acid solution by $N, N^{\prime}$-carbonyl difatty amides," Research on Chemical Intermediates, pp. 1-8, 2013. 

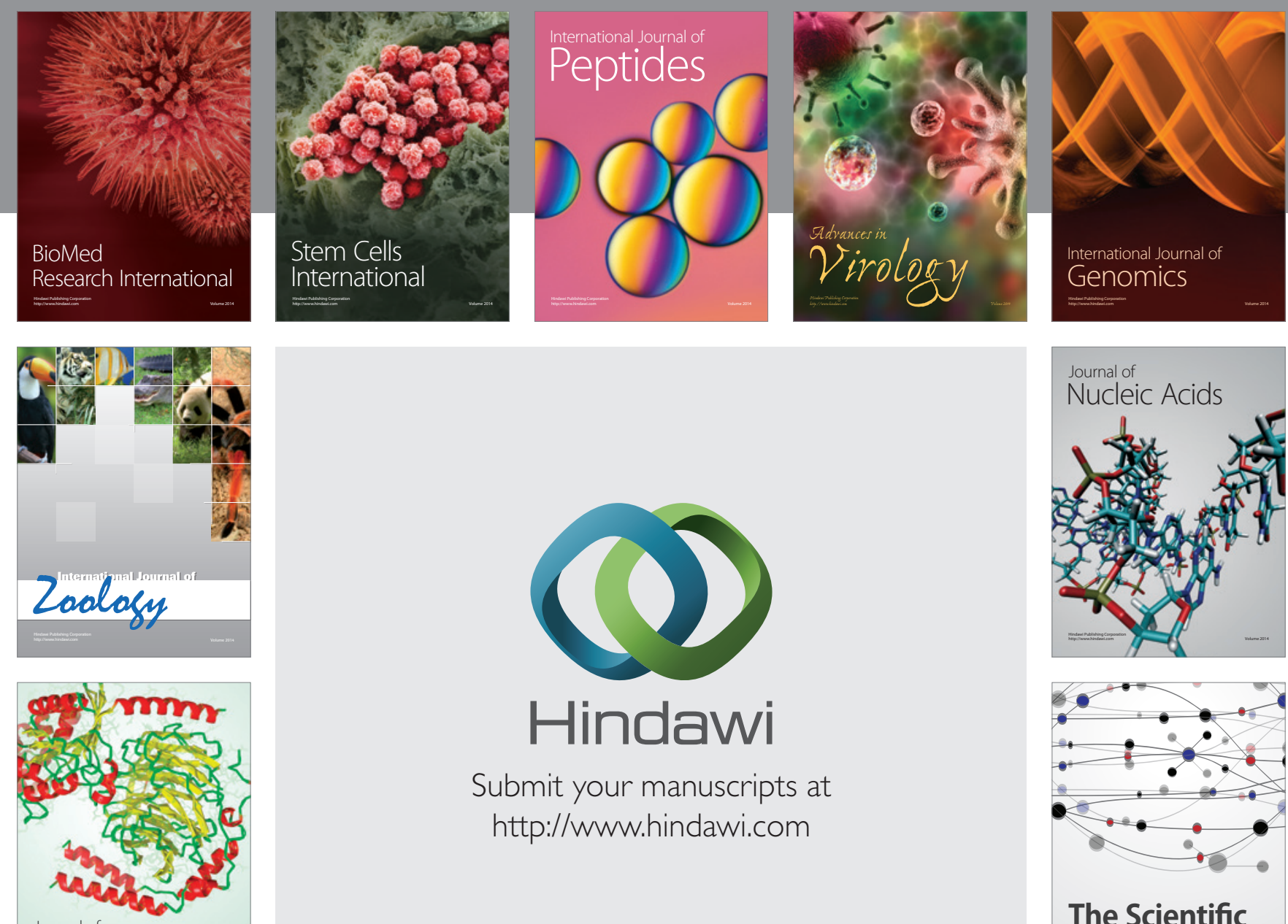

Submit your manuscripts at

http://www.hindawi.com

Journal of
Signal Transduction
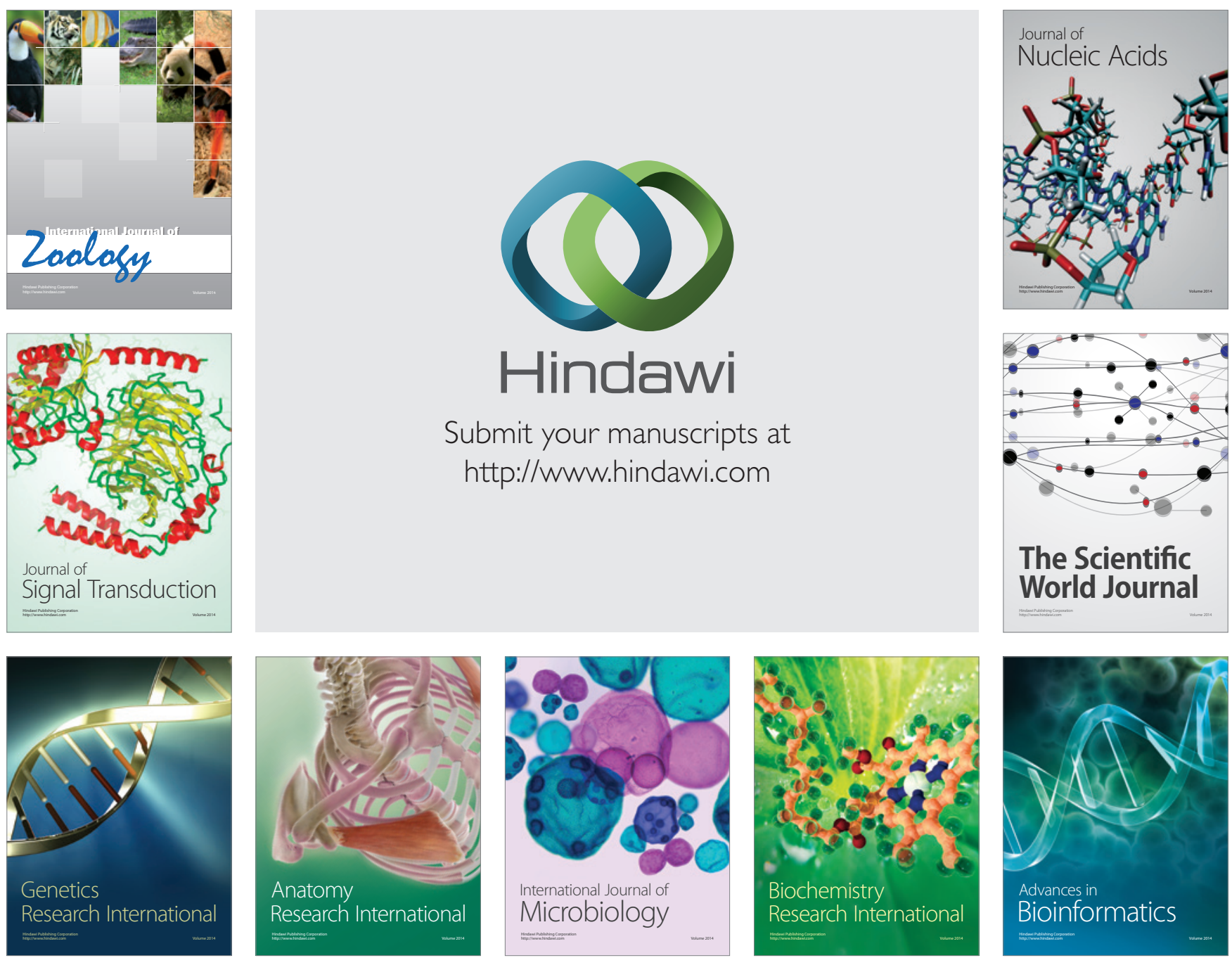

The Scientific World Journal
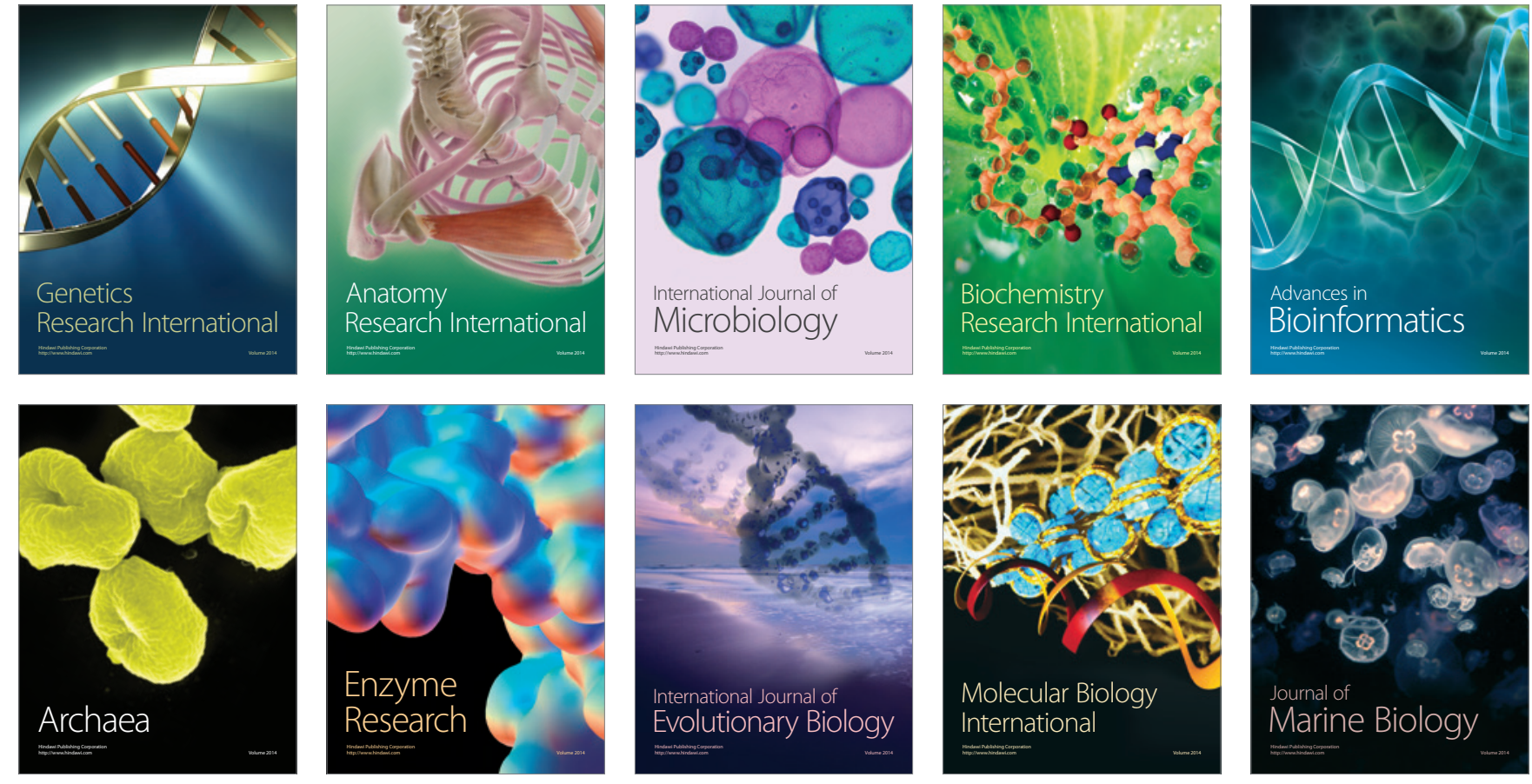